\title{
HBV and HDV Seroprevalence among Healthy People Admitted for Hepatitis B Vaccination
}

\author{
Attiya Sabeen Rahman ${ }^{1}$ Muhammad Amir ${ }^{2}$ Muhammad Asadullah Siddiqui ${ }^{3}$ Qaiser Jamal $^{1}$ \\ Mehwish Riaz ${ }^{1}$ Adnan Aziz ${ }^{4}$
}

\begin{abstract}
Background: An estimated 350 million persons worldwide are chronically infected with Hepatitis B virus (HBV). These are at increased risk of developing liver cirrhosis and hepatocellular carcinoma. The aim of the study was to determine the prevalence of Hepatitis B and co- existing Hepatitis D and to investigate the pattern of lab parameters among patients positive for hepatitis B and/or D. Methods: This is an observational cross-sectional prospective study conducted from 2009 to 2014 in Lyari General Hospital Karachi Pakistan. A total of 10270 patients were registered in the liver clinic from June 2009 to December 2014 for hepatitis B vaccination. All patients who had visited the Liver clinic of Lyari General Hospital for hepatitis B vaccination were first screened for hepatitis B, and D viruses by HBsAg, and Anti HDV antibodies and anti HCV by ELISA method. Patients who had HBsAg negative were then vaccinated. If HBsAg was found to be positive the patients have been underwent through further tests for the confirmation of hepatitis B and D (Hepatitis B Virus DNA polymerase chain reaction (PCR), hepatitis B e-antigen (HBeAg), hepatitis Be antibody (HBeAb), and if anti HDV positive then HDV RNA PCR was performed). Patients found to have a positive HBVDNA PCR with positive or negative HBeAg were treated. Patients with positive HBeAb were seroconverted. Patients with a positive anti HDV antibody underwent an HDVRNA PCR and if positive were treated. Statistical analysis was performed using SPSS (IBM SPSS Statistics 24.0). Results: A total of 10270 patients were registered in the liver clinic. Overall 206 (2\%) were found to be HBV positive, in which $26.2 \%$ had Hepatitis D co-infection. More than half (57.3\%) were male and 70.4\% were married with the mean age of $33.2 \pm 10.9$ years. About one-fourth of the total were HbeAg positive $(25.2 \%)$ and hepatitis D antibody positive (26.2\%), while $21 \%$ had HDV PCR positive and $6.3 \%$ had hepatitis C antibody positive. The mean hemoglobin was 12.2, white cell count 6052.3, viral load of HBV DNA was 44100856.97, SGPT was 63.47, albumin was 4.24 and mean INR was 1.09. Conclusion: Prevalence of Hepatitis B infection was $2 \%$ and Hepatitis D infection was present in $26.2 \%$ of hepatitis B infected patients.
\end{abstract}

Keywords: Chronic hepatitis B, chronic hepatitis C, cirrhosis, co-infection, hepatitis delta virus, epidemiology

ÖZET

Giriş: Dünya genelinde 350 milyon kişinin Hepatit B virüsü (HBV) ile kronik olarak enfekte olduğu tahmin edilmektedir. Bu kişier karaciğer sirozo ve hepatoselüler karsinom gelişimi riski altındadır. Bu çalışmanın amacı Hepatit B ve ko-enfeksiyon olarak Hepatit D virusunun prevelansını saptamak ve Hepatit B ve/ya Hepatit D pozitif hastalar arasında laboratuvar parametrelerinin örüntülerini inceleyebilmektir. Yöntem: Bu gözlemsel tanımlayıc1-kesitsel prospektif çalışma, 2009-2014 yılları arasında Lyari Genel Hastanesi, Karaçi, Pakistan'da yapıldı. Haziran 2009'dan Aralık 2014'e kadar toplam 10270 hasta karaciğer polikliniği'ne hepatit B aşılaması için kaydolmuştur. Lyari Genel Hastanesi'nde Karaciğer kliniğine hepatit B aşılaması için başvuran hastaların hepsi ilk gelişlerinde ELISA yöntemiyle hepatit B ve D virusleri için HBsAg, Anti HDV antikorları ve anti HCV için tarandılar. HBsAg negatif olan hastalar aşılandı. Ĕger HBsAg pozitif bulgulandıysa hastalara hepatit B ve D doğrulaması için ileri testler yapıldı ( Hepatit B virus DNA polimeraz zincir reaksiyonu (PCR), hepatit B e-antijeni (HbeAb) ve eğer anti HDV pozitif ise HDV RNA PCR uygulandı). Pozitif HBVDNA PCR sonucu ile pozitif ya da negatif HbeAg sonucu olan hastalar tedavi edildi. İstatiksel yöntem olarak SPSS kullanıldı (IBM SPSS Statistics 24.0). Bulgular: Karaciğr kliniğine toplamda 10270 hasta kaydoldu. Bunlardan 206'sı (\%2) HBV pozitif olarak bulgulandı ki \%26.2'de Hepatit D ko-enfeksiyonu vardı. Yarısından fazlas1 (\%57.3) erkekti ve \%70.4'ü evliydi, yaş ortlaması ise $33.2 \pm 10.9$ yıldı. Bütünün dörte birinde HBsAg pozitif (\%25.2) ve hepatit D antikoru pozitif (\%26.2) iken \%21 HDV pozitif ve \%6.3 hepatit C antikoru pozitifti. Ortalama hemoglobin değeri 12.2, beyaz küre sayısı 6052.3, HBV DNA'nın viral yükü 44100856.97, SGPT 63.47, albumin 4.24 ve ortalama INR 1.09 idi. Sonuç: Hepatit B enfeksiyonu prevelans1 \%2'dir ve Hepatit D ise hepatit B ile enfekte hastaların \%26.2'sinde bulunmaktadır.

Anahtar kelimeler: Kronik hepatit B, kronik hepatit C, siroz, ko-enfeksiyon, hepatit delta virusu, epidemiyoloji

Received / Geliş tarihi: 13.08.2018, Accepted / Kabul tarihi: 13.10.2018

${ }^{1}$ Department of Medicine. Karachi Medical and Dental College and Abbasi Shaheed Hospital, Karachi, Pakistan

${ }^{2}$ Department of Medicine, Lyari General Hospital, Karachi, Pakistan

${ }^{3}$ Department of Research, Saskatchewan Health Authority, Regina, Saskatchewan, Canada

${ }^{4}$ Department of Surgery, Civil Hospital, Karachi, Pakistan

*Address for Correspondence / Yazışma Adresi: Muhammad Asadullah Siddiqui, Department of Research, Saskatchewan Health Authority, Regina, Saskatchewan - CANADA E-mail: muhammad.siddiqui@saskhealthauthority.ca

Rahman AS, Amir M, Siddiqui MA, Jamal O, Riaz M, Aziz A. HBV and HDV Seroprevalence Among Healthy People Admitted for Hepatitis B Vaccination. TJFMPC, 2019;13(1): 60-66.

DOI: $10.21763 /$ tjfmpc.528253 


\section{INTRODUCTION}

It has been estimated that globally $15-20$ million of the population approximately, are affected with Delta virus (HDV). ${ }^{1}$ In the United States, the estimates are as high as 80000 . It is a rounded, ribonucleic acid (RNA) single-stranded virus that is enveloped in the surface antigen (HBsAg) of hepatitis $\mathrm{B}$ virus (HBV) for its replication and activity. $2,3 \mathrm{HDV}$ is a nucleocapsid that has two hepatitis D antigen (HDAg), a small HDAg (SHDAg) and large HDAg (L-HDAg). The viral replication and multiplication are supported by $\mathrm{S}$ HDAg, while the virion assembly is essentially done by the L-HDAg. Infection with HDV with HBV can be presented in two ways, co-infection, and superinfection. Co-infection means that HBV and HDV are acquired at the same time while super-infection is that the patient is already infected with HBV and then acquires or is super-infected by HDV later in time. $^{2}$

Liver cirrhosis, decompensated chronic liver disease, hepatocellular carcinoma, and death due to liver failure is the known grave complications of $\mathrm{HBV}^{4,5}$ An estimated 350 million persons worldwide are chronically infected with HBV. HBV carriers are also at an increased risk of developing the decompensated liver disease, cirrhosis, and hepatoma. It has been estimated that $15 \%$ to $40 \%$ of individuals develop these complications in their lifetime. ${ }^{4}$ HBsAg and hepatitis B surface antibody (anti-HBs) are used to screen the individuals infected with HBV. While hepatitis B core antibody (anti$\mathrm{HBc}$ ) is used to differentiate infection from immunity. ${ }^{6}$

Despite widely held assumptions of hyperendemicity, there are no previous studies done on the epidemiology of hepatitis D virus in Karachi, Pakistan. Routine testing for hepatitis D virus is rare in clinical practice, and because of low rates of case ascertainment, the overall contribution of the virus to the burden of liver disease in the region is unknown. The present study is aimed to determine the prevalence of HDV infection. Its characteristics and laboratory parameters of those infected with HDV infection, at a tertiary care facility in Karachi. The patients evaluated were infected with HBV and HDV. This study is done to create an increasing awareness regarding the epidemiology of HBV/HDV co-infection and its disease state, laboratory parameters, disease progression and consequence of co-infection of HBV and HDV. The above can guide the need for prevention, treatment and screening guidelines.

\section{METHODS}

This was an observational cross-sectional prospective study conducted from June 2009 to December 2014 in Lyari General Hospital Karachi Pakistan. A favorable ethical opinion was obtained from the Lyari General Hospital and Abbasi Shaheed hospital ethical committee for the study and the requirement for individual informed consent was waived. A total of 10270 patients were registered in the liver clinic on a pre-tested questionnaire from June 2009 to December 2014 for hepatitis B vaccination. These people came walk-in the liver clinic after having awareness regarding hepatitis B. This liver clinic is a free public care facility, which provides vaccination, investigations, and treatment for the poor.

All patients who had first visited the Liver clinic of Lyari General Hospital for hepatitis B vaccination went through the following steps on his first visit. (We can make a flow diagram of the steps)

- First, screened for hepatitis B, and D viruses by $\mathrm{HBsAg}$, and Anti HDV antibodies and anti HCV by ELISA method.

- Patients who had HBsAg negative were then vaccinated.

- If HBsAg was found to be positive then the patient underwent Hepatitis B Virus DNA polymerase chain reaction (PCR), hepatitis $\mathrm{B}$ e-antigen ( $\mathrm{HBeAg}$ ), and hepatitis $\mathrm{Be}$ antibody (HBeAb), for confirmation of HBV infection.

- If anti HDV positive then HDV RNA PCR was performed, for confirmation of HDV infection.

- If the patient was found to have a positive Hepatitis B Virus DNA PCR (viral load of $>20000 \mathrm{IU} / / \mathrm{L}$ ) with a positive or a negative HBeAg then the patient was treated.

- If the patient had a positive $\mathrm{HBe} A b$ then the patient had seroconverted and the treatment was not required.

- $\quad$ Patients with a positive anti HDV antibody were then undergone an HDV RNA PCR and if was positive (with or without HBV) were treated.

- Patients who had rt-PCR HBV DNA positive with a viral load of $>20000$ IU/L were started on treatment. 
- Patients with co-infection HBVDNA and HDVRNA positive were treated respectively (Co-infection means that $\mathrm{HBV}$ and HDV are acquired at the same time while super-infection is that the patient is already infected with HBV and then acquires or is super-infected by HDV later in time, ${ }^{1}$ this study only found patients with co-infection).

- Patients with HBVDNA with a viral load of 2000-20000 IU/L were then followed up as per EASL guidelines.

- All patients who were diagnosed hepatitis B infection and/or hepatitis D infection underwent further investigations (to see the liver functions and are also required before starting treatment) which are: complete blood count (to rule out infection and see cell counts which is important before starting treatment), urea creatinine electrolytes (to assess renal function before starting treatment, serum calcium, liver function tests, Prothrombin time, international normalized ratio, serum albumin and ultrasound abdomen.

All the above investigations were done from the hospital laboratory. Statistical analysis was performed using SPSS (IBM SPSS Statistics 20.0). Mean \pm standard deviation were computed for blood markers. Frequency and percentage was computed for categorical variables such as gender, marital status and diabetes. Independent sample t-test, and man Whitney $U$ test were utilized to assess the difference between blood markers among patient with hepatitis $b$ and co-infection

\section{RESULTS}

A total of 10270 patients were registered from June 2009 to December 2014 for hepatitis B vaccination. In 2009 there were 398, 2010 there were 2747, 2011 there were 3125, 2012 there were 1772, 2013 there were 1186 and in 2014 there were 1042 patients who had visited the Liver clinic at Lyari General Hospital for hepatitis B vaccination (Figure 1).

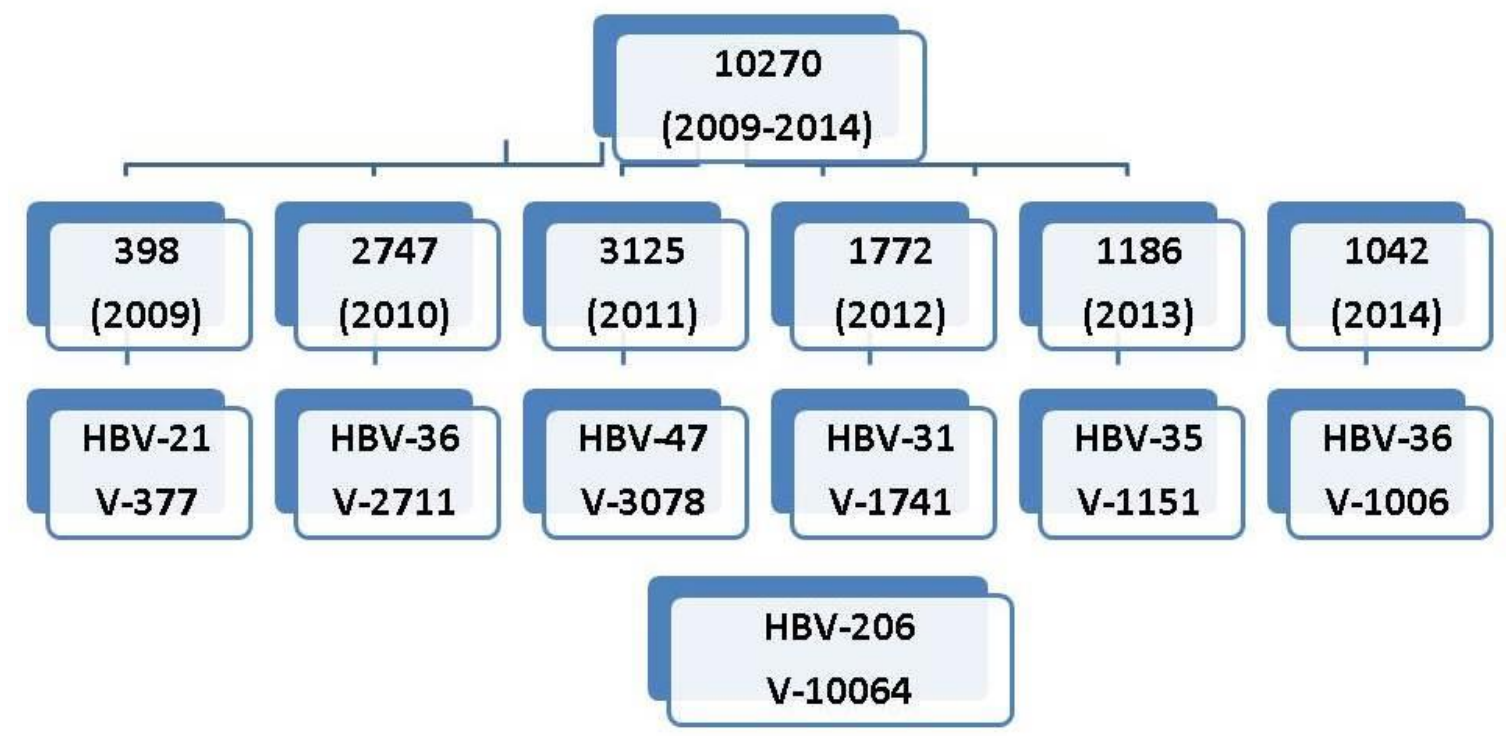

(HBV: HBs positive, V: Vaccinated)

Figure 1. Numbers of patients registered for Hepatitis B screening and vaccination

Among the vaccinated patients which were 10064 in number, in 2009, 377 patients were vaccinated, among these 145 were health care workers, 12 came in contact with hepatitis B infected individuals, 95 were patients infected with Hepatitis $\mathrm{C}$ and 125 were general population came in to get vaccinated. In 2010, 2711 patients were vaccinated, in which 453 were health care workers, 2 were thalassemia/hemophiliac, 58 came in contact with hepatitis B infected individuals, 521 were patients infected with Hepatitis C and 1393 were general population came in to get vaccinated, 22 were intravenous drug abusers, 260 were pregnant, 2 were on dialysis. 


\begin{tabular}{|c|c|c|c|c|c|}
\hline & \multicolumn{4}{|c|}{ Age } & \multirow[b]{2}{*}{ Total } \\
\hline & $1-15$ & $15-45$ & $45-60$ & $>60$ & \\
\hline 2009 & $76(4.5)$ & $109(2.4)$ & $120(4.5)$ & $72(6.6)$ & 377 (3.7) \\
\hline 2010 & $395(23.6)$ & $1202(25.9)$ & $759(28.5)$ & $355(32.6)$ & 2711 (26.9) \\
\hline 2011 & $569(34)$ & $1666(35.9)$ & $654(24.6)$ & $189(17.3)$ & 3078 (30.6) \\
\hline 2012 & $376(22.4)$ & $712(15.4)$ & $401(15.1)$ & $252(23.1)$ & 1741 (17.3) \\
\hline 2013 & $136(8.1)$ & $492(10.6)$ & $370(13.9)$ & $153(14)$ & 1151 (11.4) \\
\hline 2014 & $123(7.3)$ & $456(9.8)$ & $358(13.4)$ & $69(6.3)$ & $1006(10)$ \\
\hline
\end{tabular}

In 2011, 3078 patients were vaccinated (Table 1), among these 288 were health care workers, 4 were thalassemia/hemophiliac, 483 came in contact with hepatitis B infected individuals, 501 were patients infected with Hepatitis C and 1396 were general population came in to get vaccinated, 11 were intravenous drug abusers, 395 were pregnant. In 2012 among 1741 vaccinated patients, 59 were health care workers, 2 were thalassemia/hemophiliac, 341 came in contact with hepatitis B infected individuals, 534 were patients infected with Hepatitis C and 564 were general population came in to get vaccinated, 6 were intravenous drug abusers, 235 were pregnant. A total of 4218 patients were male and 5846 were female who were hepatitis B vaccinated from 2009 to 2014 (Figure 2).

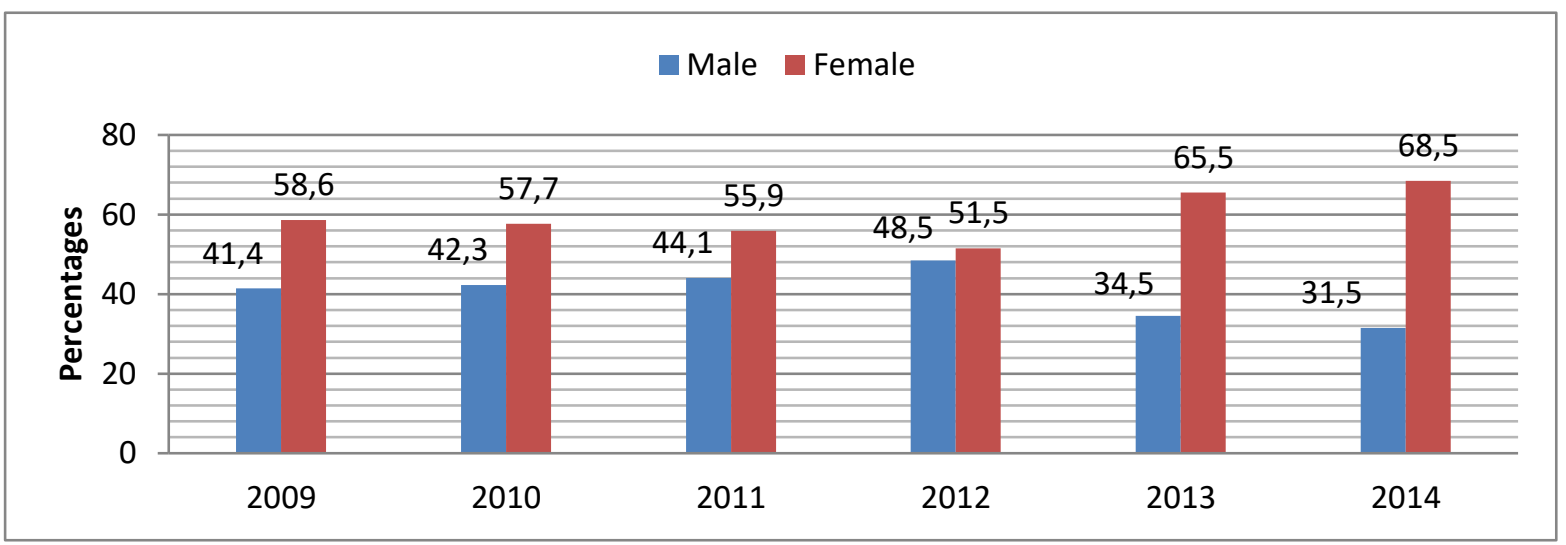

Figure 2. Hepatitis B vaccinated patients within gender - n (\%)

In 2013, 1151 patients were vaccinated, in which 33 were health care workers, 1 patient has thalassemia/hemophiliac, 275 came in contact with hepatitis B infected individuals, 339 were patients infected with Hepatitis C and 339 were general population came in to get vaccinated, 7 were intravenous drug abusers, 157 were pregnant. In 2014, among 1006 vaccinated patients, 31 were health care workers, 5 patients had thalassemia/hemophiliac, 201 came in contact with hepatitis B infected individuals, 257 were patients infected with Hepatitis $\mathrm{C}$ and 253 were general population came in to get vaccinated, 14 were intravenous drug abusers, 245 were pregnant. Among 10270 patients who were registered from June 2009 to December 2014 for hepatitis B vaccination, 206 were found to be $\mathrm{HBV}$ positive. Among HBV positive patients, $57.3 \%$ (118) were male and 70.4\% (145) were married (Table 2).

A total of 206 patients were HBV positive with a mean age of $33.2 \pm 10.9$ years and age range of 1362 years. Among this mean hemoglobin was $12.23 \pm 2.11$, white cell count was $6052.28 \pm 6933.36$ and platelets were $225073.79 \pm 87328.21$. A significant difference was observed in the level of hemoglobin level (p-0.035) and white cell count (p0.001 ) among hepatitis B patients and patients with co-infection (Table 3). 


\begin{tabular}{|c|c|c|}
\hline 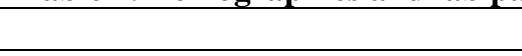 & Frequency (n-206) & Percent $(\%)$ \\
\hline \multicolumn{3}{|l|}{ Gender } \\
\hline Male & 118 & 57.3 \\
\hline Female & 88 & 42.7 \\
\hline \multicolumn{3}{|l|}{ Marital Status } \\
\hline Married & 145 & 70.4 \\
\hline Single & 58 & 28.2 \\
\hline Divorced & 2 & 1.0 \\
\hline Widow & 1 & 0.5 \\
\hline \multicolumn{3}{|l|}{ HbeAg } \\
\hline Positive & 52 & 25.2 \\
\hline Negative & 154 & 74.8 \\
\hline \multicolumn{3}{|l|}{ HbeAb } \\
\hline Positive & 149 & 72.3 \\
\hline Negative & 57 & 27.7 \\
\hline \multicolumn{3}{|l|}{ HDVAb } \\
\hline Positive & 54 & 26.2 \\
\hline Negative & 152 & 73.8 \\
\hline \multicolumn{3}{|l|}{ HDV PCR } \\
\hline Positive (Co-infected) & 44 & 21.4 \\
\hline Not required & 162 & 78.6 \\
\hline \multicolumn{3}{|l|}{ Anti HCV } \\
\hline Positive & 13 & 6.3 \\
\hline Negative & 193 & 93.7 \\
\hline \multicolumn{3}{|l|}{ Diabetes } \\
\hline Positive & 23 & 11.2 \\
\hline Negative & 183 & 88.8 \\
\hline \multicolumn{3}{|l|}{ Ultrasound } \\
\hline Normal & 124 & 60.2 \\
\hline Fatty infiltration & 19 & 9.2 \\
\hline Coarse liver & 26 & 12.6 \\
\hline Hypoechoic liver & 7 & 3.4 \\
\hline Splenomegaly & 12 & 5.8 \\
\hline Hepatomegaly & 10 & 4.9 \\
\hline Subtle changes in liver parenchyma & 8 & 3.9 \\
\hline \multicolumn{3}{|l|}{ Currently treatment? } \\
\hline Completely treated & 48 & 23.3 \\
\hline On treatment & 93 & 45.1 \\
\hline Treatment not required & 65 & 31.6 \\
\hline
\end{tabular}

(HbeAg-Hepatitis B e-antigen; HbeAb-Hepatitis Be antibody; HDVAb-Hepatitis D Virus antibody; HDV PCRHepatitis D Virus Polymerase Chain reaction; Anti HCV-Anti Hepatitis C Virus)

\section{DISCUSSION}

Our study aimed to detect the prevalence rates of hepatitis B virus infection in the community coming for hepatitis $\mathrm{B}$ vaccination. The prevalence rate of hepatitis B virus was found to be $2 \%$ and the rate of co-infection with hepatitis D was $26 \%$. Among the people coming for vaccination, majority were from the general population. $\mathrm{HBV}$ was seen more in males and at a relatively younger age (mean age 33 years). The lab parameters were largely under the normal limit, which is understandable as the diagnosis was incidental on the basis of screening.
In United States during 1996-2006 the age-adjusted prevalence of HBV was found to be $4.7 \%$, which is more than twice our reported rate. Among adults, prevalence decreased significantly among those 20 49 years of age, from $5.9 \%$ to $4.6 \%(P<.05)$ but was unchanged among those $\geq 50$ years of age. ${ }^{2,3}$ In Canada, in 1998, 970 HBV cases were reported in Canada through the National Notifiable Disease Reporting (NNDR) system, the third highest number of cases among reportable vaccine preventable diseases. The prevalence of chronic hepatitis B surface antigen ( $\mathrm{HBsAg}$ )-positive carriers among intermediate in the Aboriginal population, 
Table 3. Descriptive statistics of blood markers

\begin{tabular}{|l|c|c|c|c|}
\hline & Reference Value & Hep B & $\begin{array}{c}\text { Confected } \\
\text { (Hep B \& D) }\end{array}$ & P-value \\
\hline Hemoglobin $(\mathrm{mg} / \mathrm{dl})$ & $11-18$ & 12.41 & 11.60 & 0.035 \\
\hline White cell count $\left(/ \mathrm{mm}^{3}\right)$ & $4.5-10.5 \times 10^{3}$ & 6620.82 & 3959.01 & 0.001 \\
\hline Platelet $\left(/ \mathrm{mm}^{3}\right)$ & $150-450 \times 10^{3}$ & 224210.49 & 228252.27 & 0.79 \\
\hline Blood urea $(\mathrm{mg} / \mathrm{dl})$ & $8-25$ & 25.65 & 26.25 & 0.60 \\
\hline Creatinine $(\mathrm{mg} / \mathrm{dl})$ & $0.6-1.5$ & 0.89 & 0.86 & 0.22 \\
\hline Serum sodium(mmol/l) & $135-145$ & 140.12 & 139.43 & 0.32 \\
\hline Serum potassium(mmol/l) & $3.5-5$ & 4.1735 & 4.18 & 0.91 \\
\hline Serum chloride(mmol/l) & $100-106$ & 103.63 & 102.75 & 0.24 \\
\hline Serum bicarbonate(mmol/l) & $24-30 \mathrm{mmol} / 1$ & 24.54 & 24.73 & 0.61 \\
\hline Total bilirubin $(\mathrm{mg} / \mathrm{dl})$ & Upto $1.0 \mathrm{mg} / \mathrm{dl}$ & 0.8304 & 1.62 & 0.61 \\
\hline SGPT (IU/l) & $1-21$ & 60.51 & 453.33 & 0.69 \\
\hline Alkaline phosphatase (IU/l) & $13-39$ & 180.76 & 177.57 & 0.48 \\
\hline Albumin $(\mathrm{g} / \mathrm{dl})$ & $3.5-5$ & 4.25 & 4.18 & 0.46 \\
\hline PT (sec) & $11-13$ & 11.84 & 11.78 & 0.79 \\
\hline INR & 1.0 & 1.09 & 1.07 & 0.43 \\
\hline Serum calcium (mg/dl) & $8.5-10.5$ & 8.82 & 9.01 & 0.07 \\
\hline
\end{tabular}

(SGPT-Serum Glutamic Pyruvic Transaminase; PT- Prothrombin Time; INR- International Normalized Ratio)

Canadians is estimated to be $0.5 \%$ to $1.0 \%$ but it varies according to ethnicity, occupation and other risk factors. The prevalence of $\mathrm{HBsAg}$-positive carriers is lowest in the general population; adolescents, sexually transmitted disease clinic visitors and residents of long-term care facilities; and highest in the Inuit population and immigrant populations from Southeast Asia and Africa. The HBsAg-positive rate has been reported to be $0.4 \%$ for preadolescents, $0.3 \%$ for sexually transmitted disease clinic visitors and $0.6 \%$ for residents of long term care facilities. About $26.4 \%$ of the Inuit population demonstrates evidence of previous HBV infection (anti-HBc positive) and $6.9 \%$ are $\mathrm{HBsAg}$ positive. ${ }^{2,4}$ However the infection was seen more commonly in males peaked at the age of $30-39$ years in Canada which was similar to our study. ${ }^{6}$

The prevalence of HBV in Europe was found to be quite variable ranging from $<0.1 \%$ to as high as $8 \%$. The prevalence of hepatitis B surface antigen ( $\mathrm{HBsAg}$ ) in the general population varies widely between European countries with intermediate to high HBsAg carrier rates in Turkey $(8 \%)$ and Romania (6\%), followed by Bulgaria (4\%), Latvia (2\%), and Greece (2\%). In the Slovak Republic, Poland, Czech Republic, Belgium, Lithuania, Italy, and Germany the $\mathrm{HBsAg}$ prevalence was $0.5 \%-1.5 \%$ and in the Netherlands, Estonia, Hungary, Slovenia and Norway below 0.5 $\%$. The estimates are from different years and populations, which makes comparison difficult. ${ }^{2,7,8}$ In Northern Europe (Scandinavian countries) the prevalence rate was $<0.1 \%$ while in Western Europe it was reported between $0.1 \%-0.5 \%$. However, in Southern and Eastern Europe the carrier rates were as high as $8 \% .^{2,9,10}$

The rates in Eastern Mediterranean region extending from North Africa through the Middle East to Pakistan are diverse. Hepatitis B virus infection and its sequelae are extremely common in sub-Saharan Africa; overall hepatitis B surface antigen carrier rate in the general population is 5$20 \%$, which is amongst the highest in the world. In 1985, in Egypt, the overall prevalence of HBV was $11.7 \%$, which were reduced to $1.3 \%, 14$ to $4.2 \%$ in 2009 and 2010 in the rural population. ${ }^{2,11,12}$ In Africa the estimated HBsAg seroprevalence reached $20 \%$ from $6 \% .^{13,14}$

Coming to South East Asia, an extensive review was prepared in India estimated a prevalence rate of $4.7 \%$, which is more than double to our reported rate. ${ }^{15}$ In 2002, HBV prevalence rate in Pakistan was found to be $3.3 \%$ in one hundred 
thousand who donated blood voluntarily. ${ }^{16}$ Among the obstetric and gynecological population in Pakistan, reported a prevalence of $4.6 \%$ in women of childbearing age in $2005^{17}$. In a study conducted in North Carolina, 1191 patients having chronic HBV were studied, 499 had been tested for HDV. They reported a co-infection rate of $8 \%$, in contrast to ours which was $26 \%{ }^{18}$

If we compare our rates with other Pakistani studies our rate of co-infection was $26 \%$, which was relatively comparable. ${ }^{19}$ Zuberi $^{20}$ reported 408 cases of chronic HBV infection with $44 \%$ having delta infection. Mumtaz et al. ${ }^{21}$ studied 8721 patients with chronic HBV infection found $16.6 \%$ having hepatitis D. This concludes that Pakistan has an overall reducing prevalence rate of $\mathrm{HBV}$ infection, due to increasing awareness and use of hepatitis B vaccination, with a contrasting increase in HDV coinfection.

\section{CONCLUSION}

Prevalence of Hepatitis B infection from 2009 to 2014 was $2 \%$ and Hepatitis D infection was present in $26.2 \%$ of hepatitis B infected patients. The pattern of lab parameters was within the normal limits.

\section{REFERENCES}

1. World Health Organisation. Hepatitis D. [Online]. Available at < http://www.who.int/news-room/factsheets/detail/hepatitis-d > Last Accessed Aug 13, 2018.

2. Hwang EW, Cheung R. Global Epidemiology of hepatitis B virus infection. N A J Med Sci. 2011 4:7-13.

3. Wasley A, Kruszon-Moran D, Kuhnert W, et al. The prevalence of hepatitis B virus infection in the United States in the era of vaccination. J. Infect. Dis. 2010;202:192-201.

4. Zhang J, Zou S, Guilivi A. Epidemiology of hepatitis B in Canada. Can. J. Infect. Dis. 2001;12:345-450.

5. Muir AJ. Understanding the Complexities of Cirrhosis. Clin. Ther. 2015;37:1822-36.

6. Department of health \& human services. Centers for Disease Control and Prevention [Online]. Availaible at < https://www.cdc.gov/hepatitis/hbv/pdfs/Serolo gicChartv8.pdf> Last Accessed Aug 13, 2018.

7. Custer B, Sullivan SD, Hazlet TK, Iloeje U, Veenstra DL, Kowdley KV. Global epidemiology of hepatitis B virus. J. Clin. Gastroenterol. 2004;38:S158-68.

8. Rantala M, van de Laar MJ. Surveillance and epidemiology of hepatitis B and C in Europe - a review. Euro Surveill. 2008;13.

9. Goudeau A. European Regional Study Group. Epidemiology and eradication strategy for hepatitis B in Europe. Vaccine. 1990;8:S113S6.

10. Magdzik WW. Hepatitis B epidemiology in Poland, Central and Eastern Europe and the newly independent states. Vaccine. 2000;18 Suppl 1:S13-6.

11. Shalaby S, Kabbash IA, El Saleet G, Mansour N, Omar A, El Nawawy A. Hepatitis B and C viral infection: prevalence, knowledge, attitude and practice among barbers and clients in Gharbia governorate, Egypt. Eastern Mediterranean health journal $=$ La revue de sante de la Mediterranee orientale = al-Majallah al-sihhiyah li-sharq al-mutawassit. 2010;16:107.

12. Sherif MM, Abou-Aita BA, Abou-Elew MG, El-Kafrawi AO. Hepatitis B virus infection in upper and lower Egypt. J. Med. Virol. 1985;15:129-35.

13. Kiire CF. Hepatitis B infection in sub-Saharan Africa. The African Regional Study Group. Vaccine. 1990;8 Suppl:S107-12; discussion S34-8.

14. Kiire CF. The epidemiology and prophylaxis of hepatitis B in sub-Saharan Africa: a view from tropical and subtropical Africa. Gut. 1996;38 Suppl 2:S5-12.

15. John TJ, Abraham P. Hepatitis B in India: a review of disease epidemiology. Indian Pediatr. 2001;38:1318-25.

16. Khattak MF, Salamat N, Bhatti FA, Qureshi TZ. Seroprevalence of hepatitis B, C and HIV in blood donors in northern Pakistan. J. Pak. Med. Assoc. 2002;52:398-402.

17. Sami S, Korejo R, Bhutta SZ. Prevalence of hepatitis B and hepatitis C: a Jinnah Postgraduate Medical Center experience. J. Obstet. Gynaecol. Res. 2009;35:533-8.

18. Gish RG, Yi DH, Kane S, et al. Coinfection with hepatitis B and D: epidemiology, prevalence and disease in patients in Northern California. J. Gastroenterol. Hepatol. 2013;28:1521-5.

19. Bosan A, Qureshi H, Bile KM, Ahmad I, Hafiz R. A review of hepatitis viral infections in Pakistan. J. Pak. Med. Assoc. 2010;60:1045-58.

20. Zuberi SJ. An overview of $\mathrm{HBV} / \mathrm{HCV}$ in Pakistan. . Pak. J. Med. Res. 1998;37:12.

21. Mumtaz K, Hamid SS, Adil S, et al. Epidemiology and clinical pattern of hepatitis delta virus infection in Pakistan. J. Gastroenterol. Hepatol. 2005;20:1503-7. 